\title{
Marketing Communication Model of Komodo Island in Indonesia (In the Study of Elaboraton Likelihood Model)
}

\section{Model Komunikasi Pemasaran Pulau Komodo di Indonesia (Studi: Model Kemungkinan Elaborasi)}

\author{
Arfika Pertiwi Putri \\ Universitas Dian Nuswantoro \\ Jl. Imam Bonjol No. 207 Semarang, Indonesia \\ Email: arfika.pertiwi@dsn.dinus.ac.id
}

Received : June 30, 2021 ; Revised: July 10, 2021; Accepted: August 22, 2021

\begin{abstract}
Tourism is one of the sources of national income. Komodo Island is one of Indonesia's priority destinations. Moreover, Komodo Island is one of the products in which the Indonesian people are highly involved. In the pandemic era, tourism activities including Komodo Island have decreased. The purpose of this research was to determine an effective marketing communication model for Komodo Island in carrying out postpandemic activities in increasing interest in returning to Komodo Island. This research used Partial Least Square (PLS) analysis, involving 100 Indonesian travelers as samples, used the Elaboration Likelihood Model (ELT) theory and message composition theory for basic analysis. This research result are the marketing communication model for Komodo Island is the way the central route operates in the ELT. The effectiveness of marketing communication included the elements of communication tools, types of arguments, and message quality. Repetition in this model was not an important aspect, while prior knowledge and strategies for message acquisition were important. The internal motivation was a variable that became important for achieving tourists' satisfaction and interest in repeated visits.
\end{abstract}

Keywords: ELT; Komodo Island; Marketing Communication; Messages; Model

\begin{abstract}
Abstrak
Pariwisata merupakan salah satu sumber pendapatan negara. Saat ini di era pandemic terjadi penurunan kegiatan pariwisata termasuk di Pulau Komodo. Pulau Komodo adalah salah satu destinasi prioritas Indonesia. Terlebih pulau Komodo merupakan salah satu product high involvement untuk masyarakat Indonesia. Untuk itu penelitian ini dilakukan guna mengetahui model marketing komunikasi efektif destinasi Pulau Komodo sehingga setelah pandemic dapat dilakukan serangkaian kegiatan guna meningkatkan kembali minat kunjung ulang ke Pulau Komodo. Penelitian ini menggunakan analisis PLS melibatkan 100 sample dengan teori Elaboration Likelihood Model (ELT) dan teori penyusunan pesan. Penelitian ini menunjukkan bahwa model marketing komunikasi destinasi Pulau Komodo merupakan cara kerja central rute dalam ELT. Efektivitas marketing komunikasi terdiri dari elemen tools komunikasi, tipe argument dan kualitas pesan. Pengulangan dalam model ini bukan merupakan bagian yang penting namun pengetahuan utama dan
\end{abstract}


strategi pemenuhan perolehan pesan merupakan elemen konstruksi yang penting. Motivasi internal merupakan variable yang menjadi penting untuk mencapai kepuasan wisatawan dan minat kunjung ulang.

Kata kunci: ELT; Marketing Komunikasi; Model; Pesan ; Pulau Komodo

\section{Introduction}

Traveling activities have become one of the lifestyles of modern days. The increasing public need for tourism is supported by many external and internal factors. The value of tourism investment in Indonesia has also increased since 2017. Foreign Investment noted that from January to December 2018, the investment in Indonesian tourism in the star hotel sector was US\$525.18 million. The investment in the tourism destinations was $20 \%$ in the Riau Islands, $30 \%$ in the capital city of Jakarta, and the largest was $40 \%$ on the island of Bali.

The amount of investment is predicted to steadily increase linearly with the increasing number of foreign tourist visits to Indonesia. Based on data in 2013, there were about 8.8 million foreign tourists, and at the end of 2018, the number increased by almost $50 \%$ to 15.8 million tourists. The tourists were from the Asian region (BPKM, 2019). This trend is not much different from the BPS record in that the number of foreign tourist visits from January to April 2019 reached 5.12 million visits. This number increased by $3.22 \%$ compared to foreign tourist visits in the same period in 2018 which was 4.96 million visits (Kumparan, 2019). This is a positive signal for the trend in Indonesian tourism.
Tourism has become a lifestyle supported by the development of the economy and technology. Based on the economic development, the increasing prosperity of the community results in more opportunities to travel. The presence of technology, such as social media, allows people to be narcissistic and share their travel destinations and experience. This phenomenon turns into digital word of mouth (WOM) which makes fellow social media users interact with each other to find interesting travel destinations. Pitana (2005) claimed that the typology of tourists and lifestyle has a relationship in which this typology was based on the real needs of tourists so that the development of tourist objects was carried out following tourist segmentation. It is assumed that the typology of tourists is a description of their lifestyle that has an impact on their behavior in the destinations they visit (Utama et al., 2016).

Indonesia has developed various tourism potentials which became known as the 'New Bali'. With this breakthrough, it was expected that these tourist areas would have the same tourist visits as Bali because Bali is the main tourist attraction in Indonesia. Creating a New Bali was the government's hope that the development of the tourism sector will not only be centered in Bali. The ten new destinations are the $10 \mathrm{New} \mathrm{Ba-}$ 
li, namely Mandalika (West Nusa Tenggara), Labuan Bajo (East Nusa Tenggara), Wakatobi (Southeast Sulawesi), Morotai (North Maluku), Lake Toba (North Sumatra), Tanjung Kelayang (Bangka Belitung), Tanjung Lesung (Banten), the Thousand Islands and the Jakarta Old Town (DKI Jakarta), Borobudur (Central Java), and Bromo Tengger Semeru (East Java). From the 10 destinations, four of them are super-priority destinations, namely Lake Toba, Borobudur, Mandalika, and Labuan Bajo (Hari Widowati, 2019). Various efforts have been done to increase visits, including infrastructure improvements.

As a leading tourist destination in the Labuan Bajo area, various forms of communication were carried out as promotions for Komodo Island. As a super-priority area, the government carried out a series of promotions to increase visitors. Since 2016, based on the data from the Indonesian Ministry of Communication and Informatics, there have been several promotional activities conducted by the Ministry of Tourism, including exhibitions, sales missions, family trips inviting journalists, celebrities, bloggers, electronic media publications, print, and online media publications.

Tourism in Komodo Island has been supported in various ways, from events, infrastructures, and promotions. However, the Covid-19 pandemic has caused the tourism sector to decline. Therefore, it is necessary to create a marketing communication model to achieve maximum effectiveness. The effectiveness of the message can be seen from whether the target is persuaded by a message or not. In addition to persuasive promotions, motivation can be awakened by tourists' knowledge related to an event or a famous tourism brand. Motivation itself is divided into two types, intrinsic motivation, and extrinsic motivation. Extrinsic motivation consists of motives that are active and functioning because of external stimuli (Prihartanta, 2015). The event and the reputation of a place can motivate tourists to visit. Intrinsic motivations include the six tourist motivations, namely contemplation, exploration-social, restorative, culinary, opportunity, and novelty as well as the four tourism activities, namely physical, cognitive, affective, and adventurous activities. The correlation of motivation and tourism activities forms a pattern that shows three types of tourists, namely explorers, pleasure seekers, and adventurers (Wiyono et al., 2019).

Previous research argued that the current technology enables innovative, usable, and credible visualization of tourism data, and then maximizing the opportunity to apply principles of the Elaboration Likelihood Model (ELM) and ultimately transfer of knowledge to an array of tourism stakeholders from different backgrounds (Anne Hardy, Oskaras Vorobjovas, 2018). Another research explained the individual decisionmaking processes by using the Theory Planned Behavior (TPB) framework with the integration of meaningful constructs rooted in ELM. Therefore, the results helped the tourist application developers to apply better marketing and service strategies through effective management of tourists' central routes, pe- 
ripheral routes, normative and nonvolitional processes of tourism Location Based Service (LSB) decisionmaking (Bo Meng, 2019). This study examined which thinking routes were used by tourists when they received information about Komodo Island tourism. This study contributed as a reference of a model for postpandemic persuasion to increase tourist return visits.

\section{Theoretical Framework}

Marketing communication has a fundamental function to promote a product or a brand, including tourism. (1) Marketing communication becomes a means to enhance the value of a brand. (2) Marketing communication serves to shape consumer behavior. It informs, persuades, strengthens, and boosts the image of a brand. With the existence of communication tools and media, marketing communication messages can reach the cognitive and emotional aspects of an organization's audience (Fill, 2009).

In communication, the most important thing is the arrangement of messages. Marwell and Schmitt (1967) suggested sixteen strategies commonly used to create a message. The theory assumed that the exchange theory method was the basis for the fulfillment model in the message (B.Stiff, 2003). One will obey in exchange for something provided by the other. If one does what the other party wants, then that party will give something in return - price, approval, money, freedom from obligation, and good feeling.

ELT is a theory that can be used to analyze persuasion. ELT provides a model that shows whether a person is persuaded by a central route or a peripheral route (Stephen W. Littlejohn, 2011). The central route is identified as a stage in which a person thinks critically when he/she receives a form of persuasion. When someone processes information with the central route, he/she is actively thinking and considering a lot of information that is already known, so that he/she will respond to the argument carefully. When a change occurs, this theory indicates a relatively permanent change that will affect subsequent behavior. Meanwhile, the peripheral route occurs when someone does not use critical thinking when receiving persuasion. Therefore, it is likely that the effect is only temporary.

Factors that influence this theory are related to motivation. The motivation depends on at least three elements. The first element is personal involvement or relevance to the topic. The more important the topic is to the audience, the more likely they will think critically about the issues at hand. The second element is a different opinion. The audience tends to consider opinions from various sources. When the audience receives various information, it will be more difficult for them to assess so that they utilize the central route. The third element is the personal tendency to think critically. If someone considers opinions about something more often, it is more likely that he/she will use the central route.

Motivation in traveling is one of the important factors. Motivation can be related to the desire to move, the enthusiasm to work together, the effectiveness of work, and the inte- 
grated efforts to achieve satisfaction. These motivations can be grouped into four major groups. The first group is a motivation that is physical or physiological, including relaxation, health, and comfort (McIntosh 1977, Murphy 1985 \& Sharpley 1994). Examples are participating in sports activities and enjoying relaxing activities. The second group is cultural motivation. This includes the desire to know the culture, customs, traditions, and arts of other regions, as well as the interest in various objects of cultural heritage (historical monuments). The third group is social motivation or interpersonal motivation. This motivation relates to the social nature of a person, such as visiting friends and family, meeting work partners, doing activities with prestige value, making pilgrimages, and escaping from boring situations. The fourth group is fantasy motivation. This motivation may also be known as imagination (Harsono, 2013). With this motivation, a person will be able to escape from boring daily routines and ego-enhancements that provide psychological satisfaction. This motivation provides satisfaction that does not exist in real life and only exists in the mind or thoughts. The motivation to visit is also divided into two, namely selfcentered motivation and communityrelated motivation.

In addition, there is also extrinsic motivation. Extrinsic motivation is a motive that is active and functioning because of external stimuli. Extrinsic motivation consists of rewards, competition, prizes, praise, punishment, and environmental aspects. In this study, the motivation discussed was limited to external motivation related to environmental aspects.

Table 1: Variable and indicator

\begin{tabular}{|c|c|c|c|c|}
\hline Variable & Dimension & Indicator & Question & Code \\
\hline \multirow{11}{*}{$\begin{array}{l}\text { Marketing Com- } \\
\text { munications Expo- } \\
\text { sure }\end{array}$} & \multirow{11}{*}{$\begin{array}{l}\text { Communica- } \\
\text { tions tools (Fill, } \\
2009 \text { ) }\end{array}$} & Exhibitions & Exbition & MP1 \\
\hline & & \multirow[t]{2}{*}{ Advertisements } & Outdoor media & Mp2 \\
\hline & & & $\begin{array}{l}\text { TV and Radio } \\
\text { Advertisements }\end{array}$ & MP3 \\
\hline & & \multirow[t]{2}{*}{ Public Relations } & Youtube & MP4 \\
\hline & & & $\begin{array}{l}\text { Website and } \\
\text { Social media }\end{array}$ & MP5 \\
\hline & & Media activity & $\begin{array}{c}\text { Advertorial } \\
\text { and media pub- } \\
\text { lications }\end{array}$ & MP6 \\
\hline & & \multirow[t]{2}{*}{ Personal Selling } & Traveler Blog & MP7 \\
\hline & & & Miss Indonesia & MP8 \\
\hline & & \multirow[t]{3}{*}{ Content messages } & New Bali & P1 \\
\hline & & & $\begin{array}{c}\begin{array}{c}\text { Wonderful In- } \\
\text { donesia }\end{array} \\
\end{array}$ & $\mathrm{P} 2$ \\
\hline & & & $\begin{array}{l}\text { The Beauty of } \\
\text { Komodo Island }\end{array}$ & P3 \\
\hline
\end{tabular}




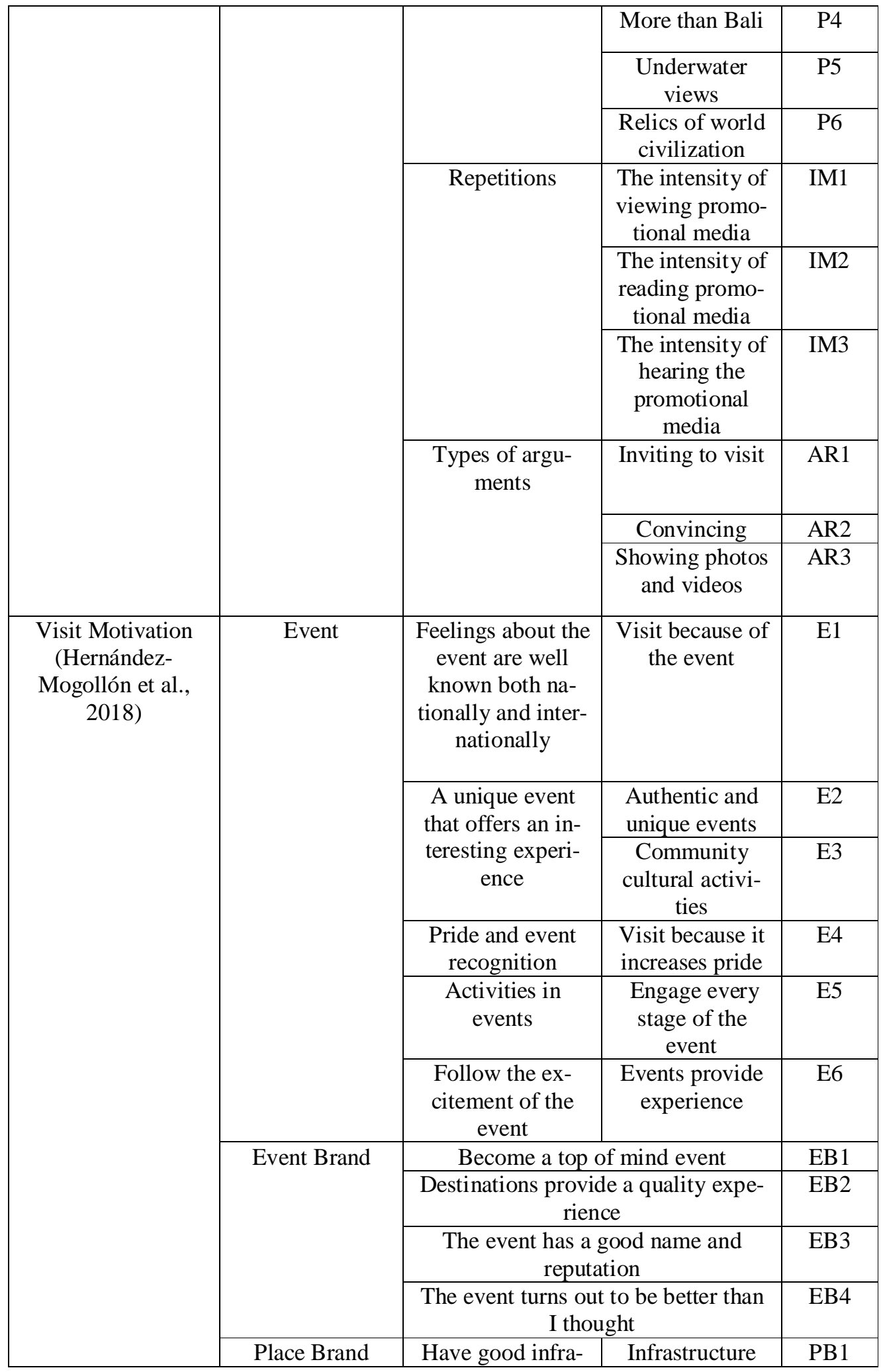




\begin{tabular}{|c|c|c|c|c|}
\hline & & structure & Lodging & PB2 \\
\hline & & $\begin{array}{l}\text { Business expan- } \\
\text { sion }\end{array}$ & Souvenirs & PB3 \\
\hline & & \multirow{2}{*}{$\begin{array}{l}\text { Local people are } \\
\text { well educated }\end{array}$} & Well educated & $\mathrm{Pb} 4$ \\
\hline & & & Cooperative & $\mathrm{Pb} 6$ \\
\hline & & Ambient & $\begin{array}{l}\text { Crowd of Des- } \\
\text { tination }\end{array}$ & $\mathrm{Pb} 7$ \\
\hline & & Attractive interior & & $\mathrm{Pb} 8$ \\
\hline & & innovative place & & $\mathrm{Pb} 9$ \\
\hline \multirow{4}{*}{$\begin{array}{l}\text { Tourist Satisfaction } \\
\text { (Martín-Santana et } \\
\text { al., 2017) }\end{array}$} & & \multicolumn{2}{|c|}{ Customer Opinion } & K1 \\
\hline & & \multicolumn{2}{|c|}{ Performance Perception } & K2 \\
\hline & & \multirow[t]{2}{*}{$\begin{array}{l}\text { Conformity of } \\
\text { Expectations }\end{array}$} & $\begin{array}{l}\text { More than ex- } \\
\text { pectation }\end{array}$ & K3 \\
\hline & & & $\begin{array}{l}\text { Beauty as ex- } \\
\text { pected }\end{array}$ & K4 \\
\hline \multirow[t]{4}{*}{$\begin{array}{c}\text { Interested to Come } \\
\text { Back }\end{array}$} & \multirow[t]{4}{*}{ Pragmatic } & \multicolumn{2}{|c|}{$\begin{array}{l}\text { Frequency of recommending desti- } \\
\text { nations }\end{array}$} & MK1 \\
\hline & & \multicolumn{2}{|c|}{ Desire to visit again } & MK2 \\
\hline & & \multirow{2}{*}{\multicolumn{2}{|c|}{$\begin{array}{c}\text { First choice of destination } \\
\text { Testimonials regarding destinations }\end{array}$}} & MK3 \\
\hline & & & & MK4 \\
\hline
\end{tabular}

\section{Research Method}

This research used 100 samples involving Indonesian people who have traveled to Komodo Island. The youngest participants were 17 years old. Researchers used geotags on Instagram to be able to find samples and then communicate privately through private messages. The primary data were questionnaires that were distributed by researchers. The data analysis was carried out using smart Partial Least Square 3.0 (PLS). PLS is a variant-based structural equation analysis (SEM) that can simultaneously test the measurement model and the structural model. The measurement model was used to test the validity and reliability, while the structural model was used to test the causality (testing hypotheses with predictive models). Researchers chose to use PLS because this method can answer the formulation of the problem posed by the researcher. In addition, PLS allows the algorithm to use a series ordinary least square (OLS) analysis so that the efficiency of the calculation of the algorithms is obtained (Ghozali, 2006). In the PLS approach, it is assumed that all measures of variance can be used in the explanation. Following the formulated hypothesis, in this study, the analysis of inferential statistical data was measured using the SmartPLS software for the measurement model (outer model), model structure (inner model), and hypothesis testing.

\section{Results and Discussion} 4.1 Fit Marketing Communication Model for Komodo Island Destinations

\subsubsection{Validity test}

From the model that has been created by the researcher and processed with PLS, a model with supporting ele- 
ments was formed to fit the marketing communication on Komodo Island. Data processing using SmartPLS 3.0 validity test were presented in 3 versions, namely conver- gent validity, average variance extracted (AVE), and discriminant validity. The data are presented in the following tables:

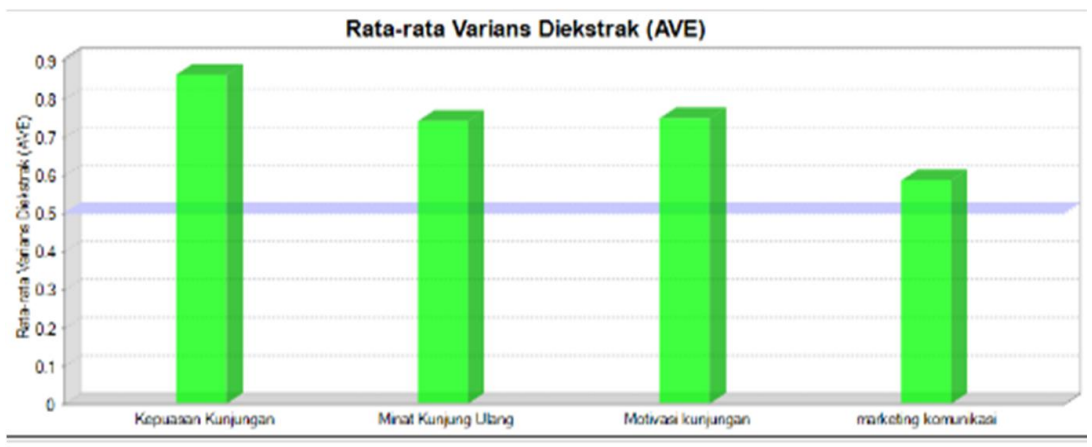

Fugure 1. AVE

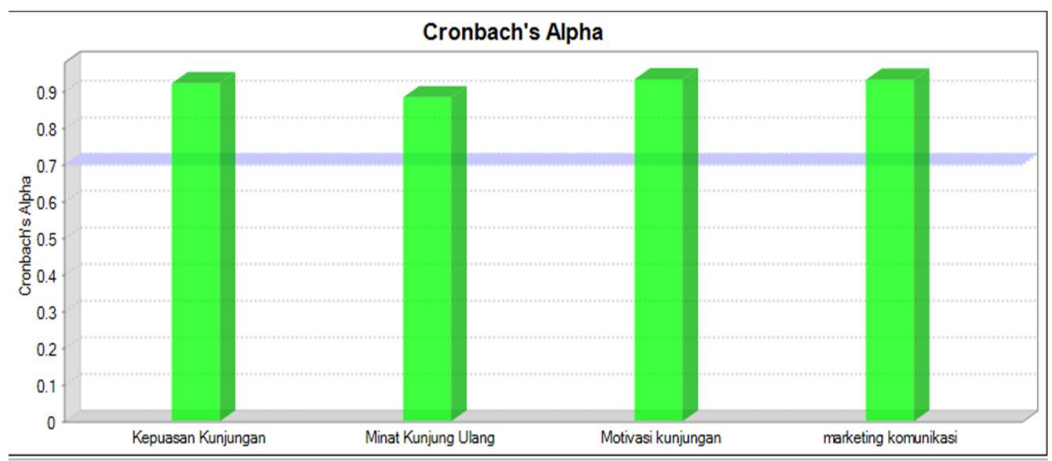

Figure 2. Crombach Alpha

Table 2. AVE and Discriminant Validity 


\begin{tabular}{|l|c|c|}
\hline \multicolumn{1}{|c|}{ Variable } & AVE & $\begin{array}{c}\text { Discriminant } \\
\text { Validity }\end{array}$ \\
\hline $\begin{array}{l}\text { Marketing } \\
\text { Communication } \\
\text { Exposure }\end{array}$ & 0,586 & 0,940 \\
\hline $\begin{array}{l}\text { External Moti- } \\
\text { vation }\end{array}$ & 0,749 & 0,947 \\
\hline $\begin{array}{l}\text { Tourist satis- } \\
\text { faction }\end{array}$ & 0,865 & 0,950 \\
\hline $\begin{array}{l}\text { Interest to } \\
\text { Come Back }\end{array}$ & 0,742 & 0,920 \\
\hline
\end{tabular}

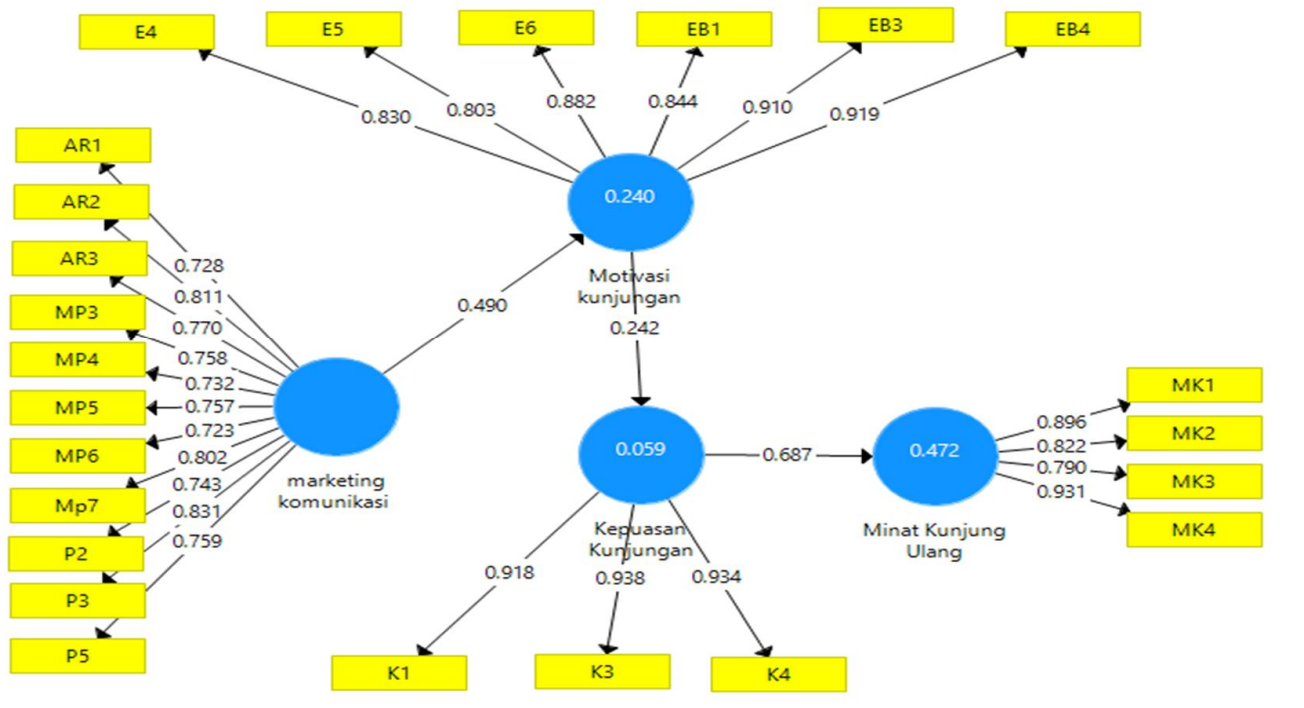

Figure 3: Model Fit
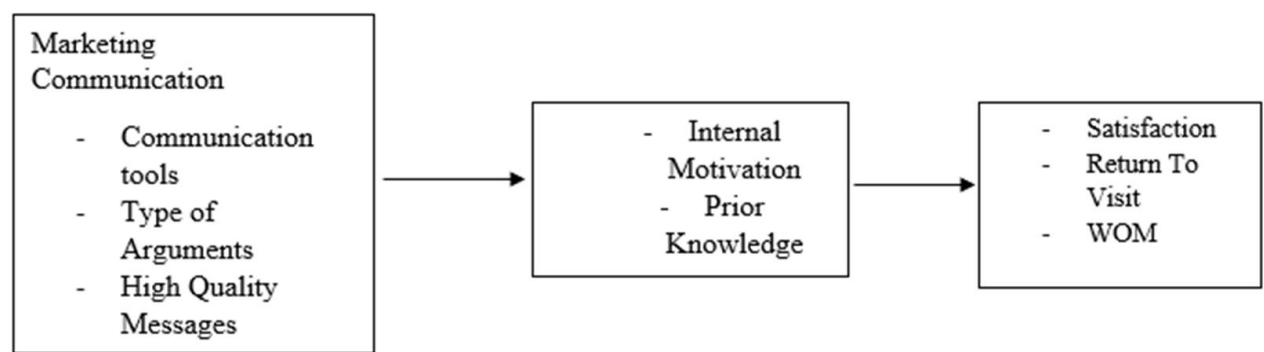

Figure 4: Marketing Communication Model of Komodo Island

Convergent Validity is a validity measurement of reflexive indi- cators as a measure of variables that can be seen from the outer loading of 
each variable indicator. An indicator is said to have good reliability if the outer loading value is above 0.70 (Sarwono, 2014). While the value of outer loading can still be tolerated up to 0.50 , the value below 0.50 can be eliminated from the analysis (Ghozali, 2015). In the existing indicators, it can be seen that several indicators are less than 0.50 so they must be eliminated. Some indicators above 0.70 are included so that the fit model is obtained.

Meanwhile, to measure discriminant validity, reflective indicators can be seen in the cross-loading between the indicators and their constructs. The second criterion for discriminant validity is to compare the roots of the Average Variance Extracted (AVE roots) for each construct with the correlation between the constructs and other constructs in the model. The model has sufficient discriminant validity if the AVE root for each construct is greater than the correlation between the other constructs. The average variance extracted (AVE) value has met the specified requirements, which is 0.5 as well as the discriminant validity value, supported by what was also suggested by Akbar, Pilcher, Perrin, Pilcher, \& Perrin (2012), Christin et al. (2014), and Zali (2016). Figures on the Average Variance Extracted (AVE) used to determine whether the average variance on the indicators in each variable is homogeneous or not from each research variable shows above 0.5. Although the marketing communication exposure variable is at this threshold, it can be said to have fulfilled it. Thus, the data collected has met the requirements to be homogeneous. Based on the table above, the discriminant validity number is above 0.6 , so all variables are declared valid.

\subsubsection{Research Variable Construct Reliability Test}

A Reliability test is used to determine whether the indicators of all research variables used are good constructs or not in forming a latent variable. The results of the construct reliability test of each variable can be seen in the following table:

Table 3 Cronbach Alpha and Composite Reliability

\begin{tabular}{|l|c|c|}
\hline \multicolumn{1}{|c|}{ Variable } & $\begin{array}{c}\text { Cronbach's } \\
\text { Alpha }\end{array}$ & $\begin{array}{l}\text { Composit } \\
\text { Reliability }\end{array}$ \\
\hline $\begin{array}{l}\text { Marketing Com- } \\
\text { munication Expo- } \\
\text { sure }\end{array}$ & 0,931 & 0,940 \\
\hline $\begin{array}{l}\text { External Motiva- } \\
\text { tion }\end{array}$ & 0,933 & 0,947 \\
\hline $\begin{array}{l}\text { Tourist satisfaction } \\
\text { Interested to Come } \\
\text { Back }\end{array}$ & 0,922 & 0,950 \\
\hline
\end{tabular}

Based on the table, the value of Cronbach's alpha and composite reli- ability that all research variables have is more than 0.7. These results 
indicate that all variables used in this study are reliable.

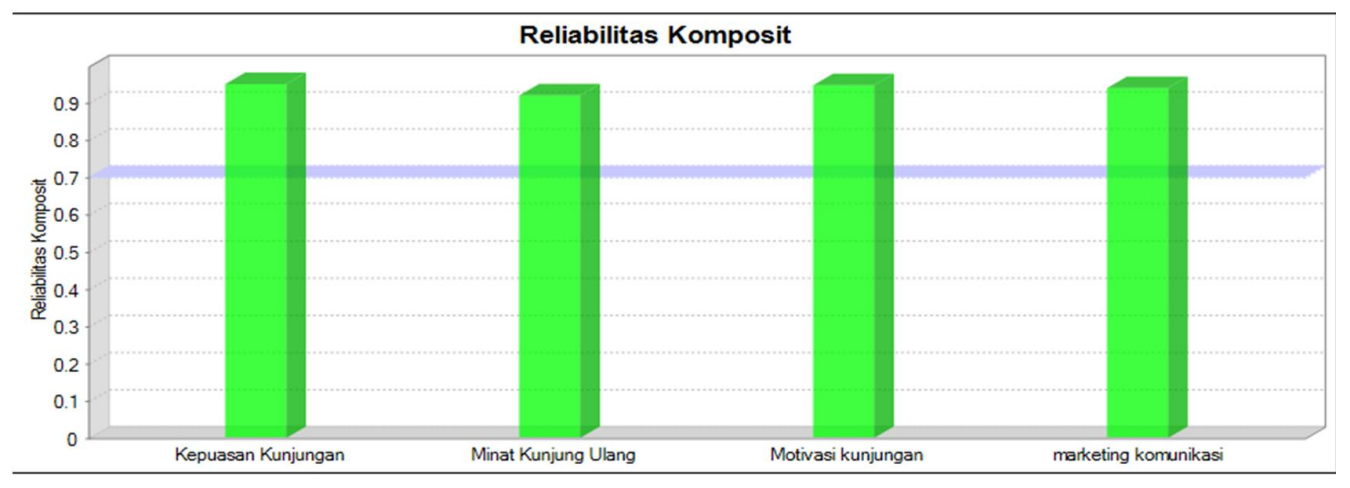

Figure 5. Composite Reliability

4.2 Communication Tools and Effectiveness of Komodo Island Marketing Communication Model In the Komodo Island marketing communication model, effective persuasion was carried out with several communication tools. The communication tools were TV and radio advertisement, YouTube videos, websites, social media, advertorial contents, and the latest print media coverage was traveler blogs. The most effective communication tools in this model were advertisement, public relations, digital marketing, and conventional media.

Persuasion using this communication tool was considered effective. The largest outer-loading construct was the traveler's blog. The personal experience of a traveler's blog is the current popular medium used as a reference for other prospective travelers. The traveler's blog is more personal, makes the reader feels closer to the writer, consists of complete reviews, and uses a comment feature that allows other potential travelers to communicate and ask questions related to destinations. Currently, travel bloggers also use social media so that their digital communication is more effective. From this fit model, it can be seen that old media still have a considerable influence as part of the marketing communication element. Advertisement is the main weapon of persuasion in the old media.

On the effectiveness of communication tools, to increase audience awareness, this model uses advertisements and public relations. Meanwhile, to increase sales, personal selling is used. Therefore, the marketing communication model for the Komodo Island destination can be made into a matrix as follows: 


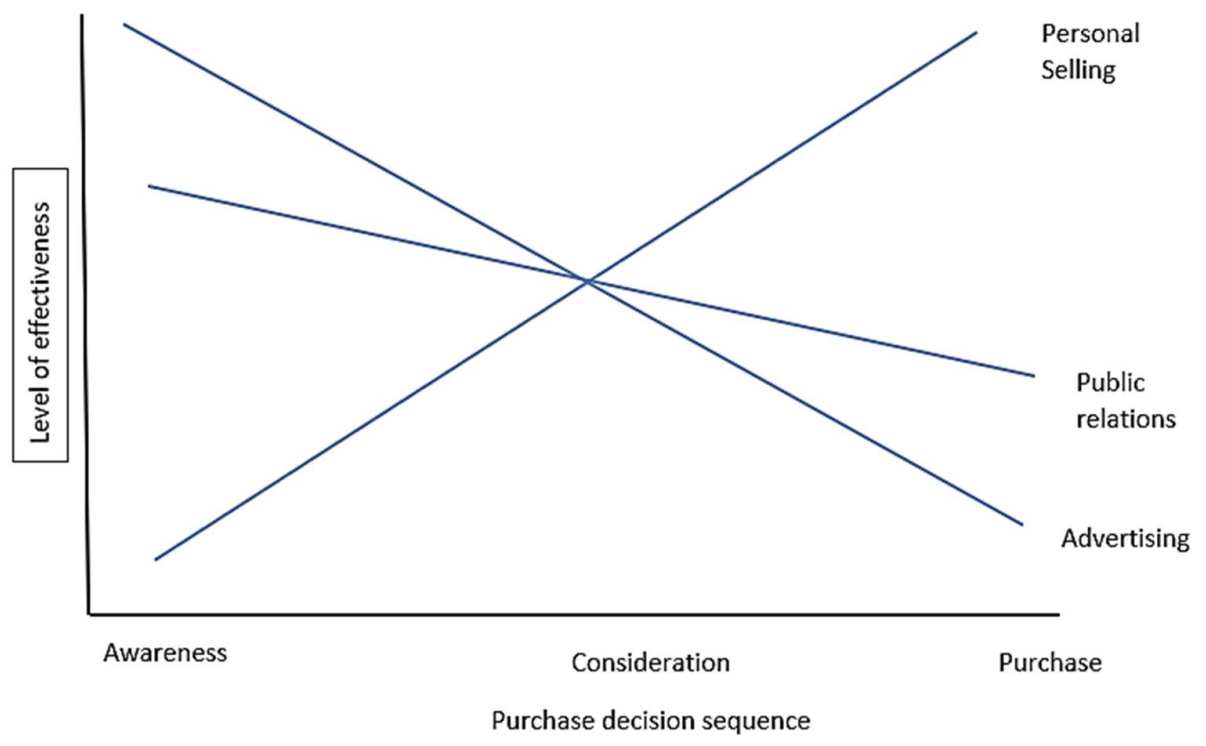

Pic 5: Effectiveness of Communication Tools

\subsection{Message and Call to Action (CAT) Marketing Communication Model for Komodo Island}

In message processing in this Komodo Island marketing communication model, the audience has several important elements. The first is the types of arguments. In this model, there are at least three types of arguments that are carried out, namely containing an invitation to visit, convincing persuasion, and showing photos or videos about Komodo Island. In ELT, it is stated that message repetition is part of the central route process. The message made at least contains a call to action and convincing persuasion with interesting photos or videos. In this construct, the greatest value is the type of argument that convinces potential travelers to visit.

The message that fits in this model consists of 3 messages, namely wonderful Indonesia, the beauty of Komodo Island, and the underwater scenery. These three messages were those that are top of mind from travelers who have visited there. Wonderful Indonesia itself was a slogan created by the government to increase visits to Indonesia which have been launched on January 1, 2011. The age of the slogan is long enough to provide evidence that this slogan has indeed hit travelers. Even though during COVID-19 the government changed and added a new slogan, namely, 'Thoughtful Indonesia', the slogan of Wonderful Indonesia is still known better by the public. Persuasion with the message of the beauty of Komodo Island became a message that hit many audiences. Komodo Island as the only one in the world is indeed the main attraction. The message about its beauty was one of the most effective messages in this model. The last message of persuasion in this model was the beauty 
of the underwater scenery. Komodo Island has been recognized by the world to have beautiful underwater scenery with coral reefs, marine life, and clear water. Activities such as snorkeling and diving on Komodo Island are essential to the experience. Thus, an effective message formula from this model was the presence of a slogan and the keywords that were the advantages of a destination, including the name of the destination.

In addition, this research used messages in marketing communications using a strategy of obtaining fulfillment in several ways, namely: promising, such as promising the underwater beauty of Komodo island; showing expertise about the positive outcome by showing photos and videos related to the beauty of Komodo Island; attributing positive feelings, many tourists had positive feelings after visiting Komodo Island proved by their recommendation to friends and colleagues; and positive altercating, visiting Komodo Island made them feel proud and better than others as internal motivation.

\subsection{Central Route as Information Processing}

In the marketing communication model for the Komodo Island destination, the audience used a central route in processing information. When the audience received a form of persuasion, they processed it with existing external motivations and then processed it with the central route. The audience actively thought critically about the information they absorbed so that they finally made a trip to Komodo Island. At least, the motivation that arouse was a person- al relevance to tourism. Tourists who visited Komodo Island must love to travel.

There are various types of motivation, one of which comes from external or environmental aspects. This marketing communication fit model made at least two elements, namely, events and brand events. In the event element, it was formulated the event could increase the pride of being present at the event. The motivation to visit included self-centered motivation or intrinsic motivation, namely the personal expectations of tourists (personal expectations) which led to a broader self-centered motivation.

The presence of social media today has created a desire to show more travel experiences that can increase followers and likes. The pride of having visited a tour that is currently popular gives a sense of satisfaction both personally and in a social network of friends. Apart from that, the existing model shows that they participated in every stage of the event. This motivation also shows the next construct, namely the event provides a variety of experiences. In addition, there are three other extrinsic motivations from this model. The first one is the brand from the event that has been carried out. If one activity is mentioned, it will automatically become the most remembered event. The second extrinsic motivation is that the event has a good reputation. When the reputation of an event is good, visitors will have a good reputation as well. The third motivation, with this reputation, guarantees the audience to get the same experience as they have been known. The existence of motivation 
that comes from inside and outside the audience makes someone more motivated to make decisions and more permanent to change. Even the factor of place and reputation of the place is not a construct in this model. As long as the place has fun events and there is strong motivation from within the visitors, the actual place is not important to them. Especially for travelers who want a wealth of experience and self-satisfaction is not just based on comfort.

4.5 There is no repetition of messages but there is prior knowledge ELT proposed by Petty has several elements that are related to message repetition and prior knowledge. In contrast, in the Komodo island marketing communication model, repetition is not an effective construct. The quality of the message is more important than the repetition of the message. The content and the types of arguments are the factors of message effectiveness in the Komodo island marketing communication model. Apart from these factors, prior knowledge remains an important element in this model. Prior knowledge relates to the level of education, the level of knowledge about Komodo Island, and the destination to be visited. Prior knowledge is one aspect of the central route. The target audience will process information armed with the information they already have (prior knowledge). After that, they will evaluate the process that will occur through the central route or peripheral route. Thus, in this case, the target audience knows Komodo Island well and has good considerations especially since this action is included in high involvement.

\subsection{Tourist Satisfaction and Inter- est in Revisit Stimulus from Visit Motivation and Information Mar- keting Communication}

The results of this marketing communication model indicated that with the existing factors, satisfaction and interest in revisiting were obtained significantly. Tourists were very satisfied with the beauty of Komodo Island which is by the promotions carried out or the expectations they formed before traveling. Thus, promotions with marketing communication tools carried out according to the fit of this model have been effective. Messages and marketing communication tools provided a stimulus for expectations and imagination which were then executed when they arrived at their destination. If the high exposure to existing communication tools is not as expected, the tourist will not be satisfied. They will file complaints that may deteriorate the reputation of the tourist area. In addition, as satisfaction arises, the tourists have more desire to come back. Their return visits not only affect them individually but also trigger them to promote the place. This promotion can then become a new tool called word of mouth through offline or online media.

\section{Conclusion}

The marketing communication model for the Komodo Island destination which influences the interest in revisitation in this ELT study concludes several important factors. First, the elements of marketing communica- 
tion consist of communication tools, messages, and types of arguments. Second, effective communication tools are personal selling, public relations, and advertising. Third, message quality is a very important element with the messages. In addition, this study concludes three messages that become top of mind, namely Wonderful Indonesia, the Beauty of Komodo Island, and the Underwater Scenery.

The types of arguments invite a visit and provide evidence of the beauty of the destination. In this study, unlike ELT with the element of message repetition, the marketing communication model in this study focuses on message quality and types of arguments. In addition, there is a strategy to fulfill the acquisition that is to achieve the effectiveness of the model.

This research also concludes that this communication marketing model uses a central route with prior knowledge as the important aspect. The motivation that comes from within the individual is more influential compared to external motivation. The fit of this marketing communication model for Komodo Island shows the satisfaction of visits and interest in revisitation. The effect of this satisfaction and interest in returning is the emergence of electronic and traditional word of mouth (WOM). Recommendation becomes one of the most important aspects in the selling stage as it results in greater trust.

\section{References}

Anne Hardy, Oskaras Vorobjovas, P.

R. E. (2018). Enhancing knowledge transfer in tourism: An Elaboration Likelihood
Model approach. Journal of Hospitality and Tourism Management, 37(December), 33-41.

https://doi.org/https://doi.org/10 .1016/j.jhtm.2018.09.002

B.Stiff, J. ; P. A. M. (2003). Persuasive Communication. In 2 (p. 239). The Guildford Press. https://books.google.co.id/books ?id=YnXk9Txuov0C\&pg=PA2 $39 \& 1 p g=P A 239 \& d q=$ marwell $+\mathrm{s}$ chimmit+messages \&source $=\mathrm{bl}$ \&ots=wylrqglNQ4\&sig=ACfU3 U1rS1CNjjBXs43CO7EL_rRTO Yl0hQ\&hl=id\&sa $=X \& v e d=2 a h$ UKEwj5n5d6YfzAhUkmuYKHW97BMsQ 6AF6BAgWEAM\#v=onepage\& $\mathrm{q}=$ marwell schimmit messages \& $\mathrm{f}=\mathrm{false}$

BPKM. (2019). Ini Negara dengan Investasi Pariwisata Terbanyak di Indonesia. https://www.investindonesia.go. id/id/artikel-investasi/detail/ininegara-dengan-investasipariwisata-terbanyak-diindonesia

Fill, C. (2009). Marketing Communications: Interactive... 5th Ed.

Hari Widowati. (2019). Harapan Tinggi dari Kerja Besar Mendandani 10 Bali Baru. Kata Data. https://katadata.co.id/yurasyahru 1/berita/5e9a50d86783b/harapan -tinggi-dari-kerja-besarmendandani-10-bali-baru

Hernández-Mogollón, J. M., Duarte, P. A., \& Folgado-Fernández, J. A. (2018). The contribution of 
cultural events to the formation of the cognitive and affective images of a tourist destination. Journal of Destination Marketing and Management, 8(July 2016), 170-178. https://doi.org/10.1016/j.jdmm.2 017.03.004

Kumparan, T. (2019). BPS Merilis Data Perkembangan Pariwisata Bulan April 2019. Kumparan.Com.

https://kumparan.com/kumparan travel/bps-merilis-dataperkembangan-pariwisatabulan-april-20191rFodFSfD09/full

Martín-Santana, J. D., Beerli-Palacio, A., \& Nazzareno, P. A. (2017). Antecedents and consequences of destination image gap. Annals of Tourism Research, 62, 13-25. https://doi.org/10.1016/j.annals. 2016.11.001

Prihartanta, W. (2015). Teori-Teori Motivasi. Jurnal Adabiya, Tahun 2015, Vol. 1 No.(83), 1-
11. https://www.academia.com

Stephen W. Littlejohn, K. A. F. (2011). Theories of Human Communication: Tenth Edition. https://books.google.co.id/books ?id=dfUYAAAAQBAJ\&lpg=P $\mathrm{P} 1 \& \mathrm{dq}=$ little john\&pg $=\mathrm{PP} 1 \# \mathrm{v}=$ onepage $\& \mathrm{q}=\mathrm{li}$ ttle john $\& \mathrm{f}=$ false

Utama, R., Bagus, I. G., Dhyana, U., \& Bali, P. (2016). BALI. March. https://doi.org/10.13140/RG.2.1 .4583 .9125

Wiyono, B. P. A., Kusuma, H. E., Sinatra, F., \& Tampubolon, A. C. (2019). Tipe Wisatawan Berdasarkan Korelasi Motivasi Dan Kegiatan Di Tempat Wisata (Studi Kasus: Indonesia). Tataloka, 21(2), 314.

https://doi.org/10.14710/tatalok a.21.2.314-327 